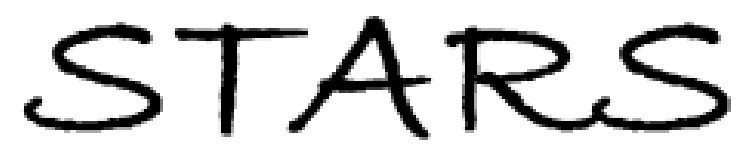

University of Central Florida

STARS

Faculty Bibliography 2010s

Faculty Bibliography

$1-1-2013$

\title{
American Philosophy: The Basics by Nancy Stanlick
}

Peter Olen

University of Central Florida

Find similar works at: https://stars.library.ucf.edu/facultybib2010

University of Central Florida Libraries http://library.ucf.edu

This Book Review is brought to you for free and open access by the Faculty Bibliography at STARS. It has been accepted for inclusion in Faculty Bibliography 2010 s by an authorized administrator of STARS. For more information, please contact STARS@ucf.edu.

\section{Recommended Citation}

Olen, Peter, "American Philosophy: The Basics by Nancy Stanlick" (2013). Faculty Bibliography 2010 s.

4493.

https://stars.library.ucf.edu/facultybib2010/4493

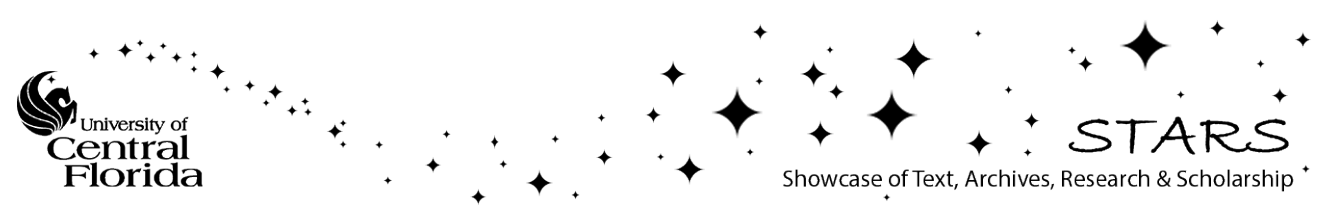


American Philosophy: The Basics By Nancy Stanlick

Author(s): Peter Olen

Source: Transactions of the Charles S. Peirce Society, Vol. 49, No. 4, Joseph Ransdell and His Legacy (Fall 2013), pp. 578-580

Published by: Indiana University Press

Stable URL: https://www.jstor.org/stable/10.2979/trancharpeirsoc.49.4.578

JSTOR is a not-for-profit service that helps scholars, researchers, and students discover, use, and build upon a wide range of content in a trusted digital archive. We use information technology and tools to increase productivity and facilitate new forms of scholarship. For more information about JSTOR, please contact support@jstor.org

Your use of the JSTOR archive indicates your acceptance of the Terms \& Conditions of Use, available at https://about.jstor.org/terms 
Nancy Stanlick

\section{American Philosophy: The Basics}

London: Routledge, 2013. 174 pp with index.

In 174 pages American Philosophy: The Basics covers the American philosophical tradition from its European roots to some of its contemporary leanings. The stated goal of the book is to give an overview of American philosophy and "explain what makes American philosophy a national or cultural philosophical tradition." This is a particularly tall order for such a short book, and it might be understandable if Stanlick necessarily omits numerous thinkers from the canon. Overall, the book succeeds at giving a quick overview of the history of American philosophy.

The text covers a fairly diverse selection of philosophers. Starting from Jonathan Edwards' Calvinist theology, the book moves through early American social and political thought, and the European enlightenment ideals that underwrite them, as found in revolutionary era thinkers such as Thomas Jefferson, Thomas Paine, and Benjamin 
Franklin. The rest of the chapters quickly address New England transcendentalism and classical pragmatism. The book ends with two quick summaries of "recent" developments in American philosophy split between metaphysics, epistemology, and the philosophy of science; and a second section on social, political, and ethical writings. The latter section includes summaries of recent writings on feminist ethics and African American social thought. Although these themes are particularly welcome, the book would have benefited by addressing feminist and African American contributions not just to ethics or social thought, but also to debates in epistemology or the philosophy of science.

The author's intended audience is undergraduates taking an American philosophy course or those wholly uninformed about the American philosophical tradition. Although the book serves as a helpful summary of various views in the American intellectual tradition, it would need to be supplemented by a substantial amount of primary texts to provide enough course material for a semester. The text does not contain enough critical commentary to function as a secondary resource by itself, but could function alongside additional secondary material.

This last point is particularly telling about the book's goals. Stanlick manages to introduce and explain numerous classic philosophical problems throughout the text (e.g., the mind-body problem, the problem of freewill, arguments for God's existence, etc . . .) and provides a glossary at the end of the book, but does not do much to explore any of the issues in-depth. In part this is because of the overview nature of the text, but additional explanations, as well as a longer list of secondary sources, would have gone a long way in strengthening the author's overall approach. This is an interesting, and I think helpful, approach for a lower-level philosophy text: it provides clear exposition of philosophical terminology while never straying from the overall goal of exploring the American philosophical tradition.

One initial problem is the author's narrative commitment to what makes American philosophy uniquely American. Stanlick argues that what is indicative of American philosophy is more of an emphasis on "what we can do with theories, principles, and arguments" than with theoretical or abstract problems. While we may be able to see this emphasis in some of the classical pragmatists and early American intellectuals, I think it's difficult to claim that such an emphasis is indicative of all American philosophy.

Additionally, seemingly major American philosophers are simply absent. Though discussions of Charles Sanders Peirce, William James, John Dewey, and Richard Rorty compose the pragmatism chapter, no mention is made of C.I. Lewis or Sidney Hook. Recent pragmatists, outside of W.V.O Quine and Rorty, are missing from both the pragmatism chapter and later chapters on contemporary developments in American philosophy. It seems reasonable to expect some mention of 
Robert Brandom's analytic pragmatism, the contemporary revival of Peirce's philosophy, Cheryl Misak's extensive work on American pragmatism (although one of her edited volumes is mentioned in a "further readings" sections), Susan Haack's epistemology, or Richard Shusterman's work on embodiment and pragmatism. Although not American in genesis, 19th Hegelianism (as especially seen in the St. Louis and Ohio Hegelians) does not appear in the book. Perhaps more importantly, the new and critical realists are not even mentioned. Surely the new and critical realists count as a distinct, albeit short-lived, instance in the history of American philosophy. Problematically, such groups represent American philosophers largely unconcerned with the practical application of their theories, principles, arguments.

To some degree this is understandable - given the author's goal of offering a basic synopsis of American philosophy, it would be impossible not to omit various thinkers from the text. Perhaps to combat exactly these kinds of concerns, Stanlick provides a guide for further reading at the end of each chapter. Some of these lists are particularly welcome and highlight a swath of literature normally ignored in overviews of American philosophy. The inclusion of primary and secondary sources pertaining to Native American thought should be seen as especially welcome and provides undergraduate students a guide to traditionally marginalized aspects of American philosophy.

Yet these omissions become increasingly problematic once one remembers Stanlick's narrative commitments. Most of the omitted philosophers are not indicative of Stanlick's narrative commitment- that what picks out American philosophy as distinctly "American" is an emphasis on the practical applicability of ideas-making the omission of these figures particularly problematic for the book. Although Stanlick largely succeeds in her goal of presenting a basic overview of American philosophy, her narrative commitment is somewhat unconvincing as a historical claim.

Objections aside, American Philosophy: The Basics succeeds in its goal of offering a quick, accessible overview to a fairly wide-range of intellectual figures. It cannot function as a standalone text, but this does not seem to be the author's intention. The book's low price ensures that it is an accessible introductory text for undergraduate students. Overall, I would recommend using Stanlick's book as additional supplementary text for lower-level American philosophy courses or in an introduction to philosophy course that pays close attention to the American intellectual tradition.

Peter Olen

University of Central Florida

PeterOlen@gmail.com 